\title{
Population variation and differences in serum leptin independent of adiposity: a comparison of Ache Amerindian men of Paraguay and lean American male distance runners Richard G Bribiescas*1 and Matthew S Hickey²
}

\author{
Address: ${ }^{1}$ Reproductive Ecology Laboratory, Department of Anthropology, Yale University, New Haven, CT 06520-8277, USA and ${ }^{2}$ Department \\ of Health and Exercise Science, 220 Moby-B Complex, Colorado State University, Fort Collins, CO 80523-1582, USA \\ Email: Richard G Bribiescas* - richard.bribiescas@yale.edu; Matthew S Hickey - Matthew.Hickey@ColoState.edu \\ * Corresponding author
}

Published: 30 August 2006

Nutrition \& Metabolism 2006, 3:34 doi:10.1 186/1743-7075-3-34
Received: 04 May 2006

Accepted: 30 August 2006

This article is available from: http://www.nutritionandmetabolism.com/content/3///34

(C) 2006 Bribiescas and Hickey; licensee BioMed Central Ltd.

This is an Open Access article distributed under the terms of the Creative Commons Attribution License (http://creativecommons.org/licenses/by/2.0), which permits unrestricted use, distribution, and reproduction in any medium, provided the original work is properly cited.

\begin{abstract}
Background: Serum leptin variation is commonly associated with fat percentage (\%), body mass index (BMI), and activity. In this investigation, we report population differences in mean leptin levels in healthy men as well as associations with fat \% and BMI that are independent of these factors and reflect likely variation resulting from chronic environmental conditions.
\end{abstract}

Methods: Serum leptin levels, fat \%, and BMI were compared between lean American distance runners and healthy Ache Native Americans of Paraguay. Mean levels were compared as were the regressions between fat \%, BMI, and leptin. Comparisons were performed between male American distance runners $(n=13$, mean age $32.2 \pm 9.2$ SD) and highly active male New World indigenous population (Ache of Paraguay, $n=20$, mean age $32.8 \pm 9.2$ ) in order to determine whether significant population variation in leptin is evident in physically active populations living under different ecological circumstances independent of adiposity and BMI.

Results: While the Ache were hypothesized to exhibit higher leptin due to significantly greater adiposity (fat \%, Ache 17.9 $\pm 1.8 \mathrm{SD}$; runners $9.7 \pm 3.2$, $\mathrm{p}<0.000 \mathrm{I}$ ), leptin levels were nonetheless significantly higher in American runners (Ache $1.13 \mathrm{ng} / \mathrm{ml} \pm 0.38 \mathrm{SD}$; runners $2.19 \pm 1.15 ; \mathrm{p}<$ 0.007). Significant differences in the association between leptin and fat $\%$ was also evident between Ache and runner men. Although fat $\%$ was significantly related with leptin in runners $(r=0.90, p<$ $0.000 \mathrm{I})$ fat $\%$ was negatively related in Ache men $(r=-0.50, p<0.03)$.

Conclusion: These results illustrate that chronic ecological conditions in addition to activity are likely factors that contribute to population variation in leptin levels and physiology. Population variation independent of adiposity should be considered to be an important source of variation, especially in light of ethnic and population differences in the incidence and etiology of obesity, diabetes, and other metabolic conditions.

\section{Background}

Leptin is a polypeptide hormone that is secreted primarily by adipose tissue and acts as a lipostat to the hypothala- mus affecting numerous aspects of physiology including metabolism, immune function, and reproduction [1]. While leptin is often highly correlated with fat percentage, 
other sources of variation are important. Diet [2], activity [3], genetics [4], and infectious status [5], all contribute to leptin variation to some extent independent of adiposity. Other tissues besides fat also contribute to leptin levels although their relative contribution is minor [6].

Although adiposity is a major source of variation in leptin levels, significant population variation is evident with leptin being significantly lower in non-industrialized populations compared to more developed communities [7-9]. The source of this variation remains to be fully described but chronic environmental and nutritional conditions have been suggested [10]. Among Ache Amerindian women of Paraguay, such marked variation has been reported. Curiously, Ache women exhibit leptin levels that are not significantly different from American anorectic women despite significantly greater adiposity (Figure 1) [11]. Comparisons of leptin among Ache men are less well described.

To determine whether differences in the association between leptin and adiposity extend also to Ache men, this investigation compares Ache male leptin with a group of comparable adiposity in a developed society, American runners. The significance of this comparison is gain insights into ethnic variation in leptin physiology and to provide a greater understanding of the etiology of metabolic syndrome among Native American groups [12,13]. Both groups are lean and exert significant physical activ-

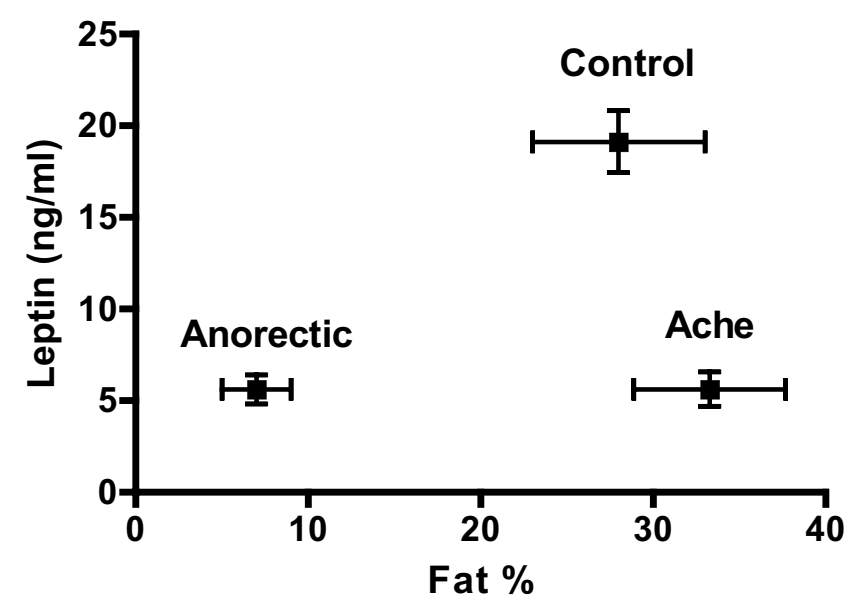

Figure I

Mean leptin comparisons between Ache women and American anorectics and controls. Mean comparisons of leptin and fat percentage between Ache women (leptin 5.6 $\pm 3.2 \mathrm{ng} / \mathrm{ml}$; fat \% $33.3 \pm 4.4 \mathrm{SD})$, American Anorectics (5.6 \pm $3.7 ; 7.0 \pm 2.0$ ), and American controls (I $9.1 \pm 8.1 ; 28.0 \pm 5.0$ ) (Ache leptin vs. Anorectic, $p<0.98$; Control, $p<0.0001$; Ache fat \% vs. Anorectic, $p<0.000$; Control, $p<0.004$ ) [II]. ity. While the Ache do not engage in habitual exercise, their activity levels and aerobic profiles reflect significant daily physical exertion resulting from their daily regimen of manual farming and foraging for food products in the surrounding forest [14]. This comparison allows the assessment of interpopulation variation in leptin associations with adiposity within a non-pathological context. It was therefore hypothesized that according to our current understanding of leptin physiology, 1) leptin should be higher in the group exhibiting greater adiposity; 2) leptin should be positively associated with adiposity in each group.

\section{Methods}

Leptin and anthropometric data was collected from the Ache by the author and compared with pre-exercise control measures from runners reported in Hickey et al. [15]. Specific anthropometric and hormone assessment methods are available from their respective references [9]. Although leptin assay methods and kits are highly correlated [16], these data sources were chosen since each utilized similar leptin iodine 125 based radioimmunoassays, thereby reducing interlaboratory variability. Unpaired 2 tailed t-tests of fat $\%$, BMI, age, and leptin were conducted. Welch's correction was employed when variances were significantly different. Standard linear regression was used to determine associations between anthropometric measures and leptin. Comparison of regression slopes was conducted using the methods of Zar, 1999 [17]. Results were calculated using Prism 4.0 for Macintosh (GraphPad Software, San Diego, CA). Alpha was set at 0.05 . These protocols were approved by the human subjects protection committees of Yale and Colorado State Universities.

\section{Results}

Despite significantly higher body fat percentage (Ache $17.9 \pm 1.78$; Runners $9.7 \pm 3.2 ; \mathrm{p}<0.0001)$, Ache leptin was significantly lower than runners (Ache $1.13 \pm 0.38$; runners $2.2 \pm 1.15 ; \mathrm{p}<0.007)$. There was no significant difference in BMI (Ache 23.8 \pm 1.4 ; Runners $22.9 \pm 2.0 ; \mathrm{p}$ $<0.16$ ) or age (Ache $32.8 \pm 16.1$; runners $32.2 \pm 9.2$; $\mathrm{p}<$ 0.89 ) (Figures 2a-d). In addition, the associations between leptin and fat percentage were quite different. While runners exhibited the expected positive relationship between leptin and fat $\%(r=0.90, p<0.0001)$, the association in Ache men was negative $(r=-0.50, p<0.03)$, although the association is not significant with the elimination of one outlier (Figure 3a). Not surprisingly, the slopes were significantly different $(\mathrm{p}<0.0001, \mathrm{~F}=40.0)$. Similarly, leptin associations with BMI were highly significant among the runners $(r=0.75, p<0.003)$ but not Ache $(r=-0.17, p<0.50)$. Again, the slopes are significantly different $(\mathrm{p}<0.001, \mathrm{~F}=13.5)$ (Figure 3b). 
A

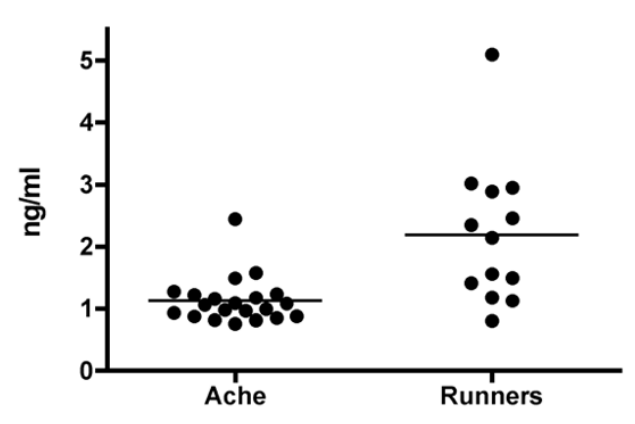

C

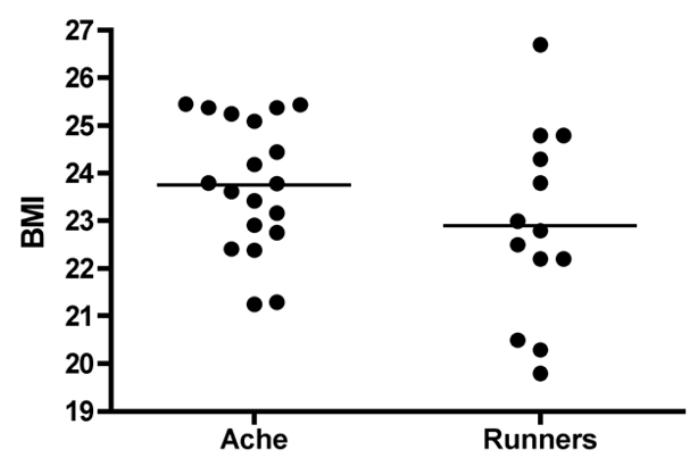

B

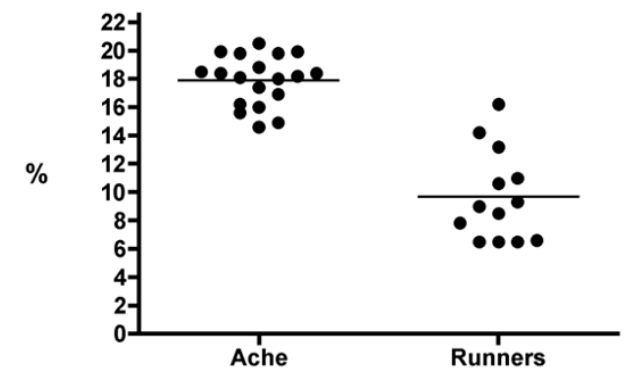

D

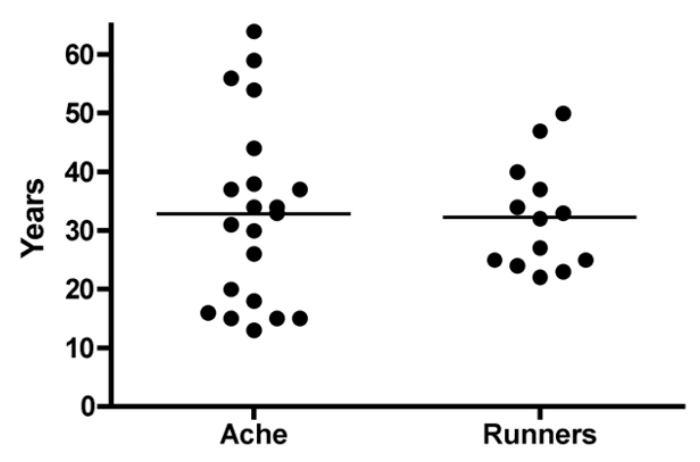

Figure 2

Mean leptin comparisons between Ache men and American male runners. Mean comparisons between Ache men and runners (a) Leptin ( $<<0.007)$, (b) Fat \% ( $<0.000 \mathrm{I})$, (c) BMI $(p<0.16)$, and (d) age $(p<0.89)$.

\section{Discussion}

The hypothesis that leptin should be higher in the group exhibiting greater adiposity was not supported in this investigation. In addition, the hypothesis that leptin should be positively associated with adiposity is only evident among American runners. Therefore other sources of leptin variation, particularly among the Ache, need to be considered. The exact mechanisms that underlie population variation independent of adiposity remain unclear, however genetic differences between populations, chronic environmental influences such as maternal/fetal or childhood nutritional status, and acute lifestyle differences 

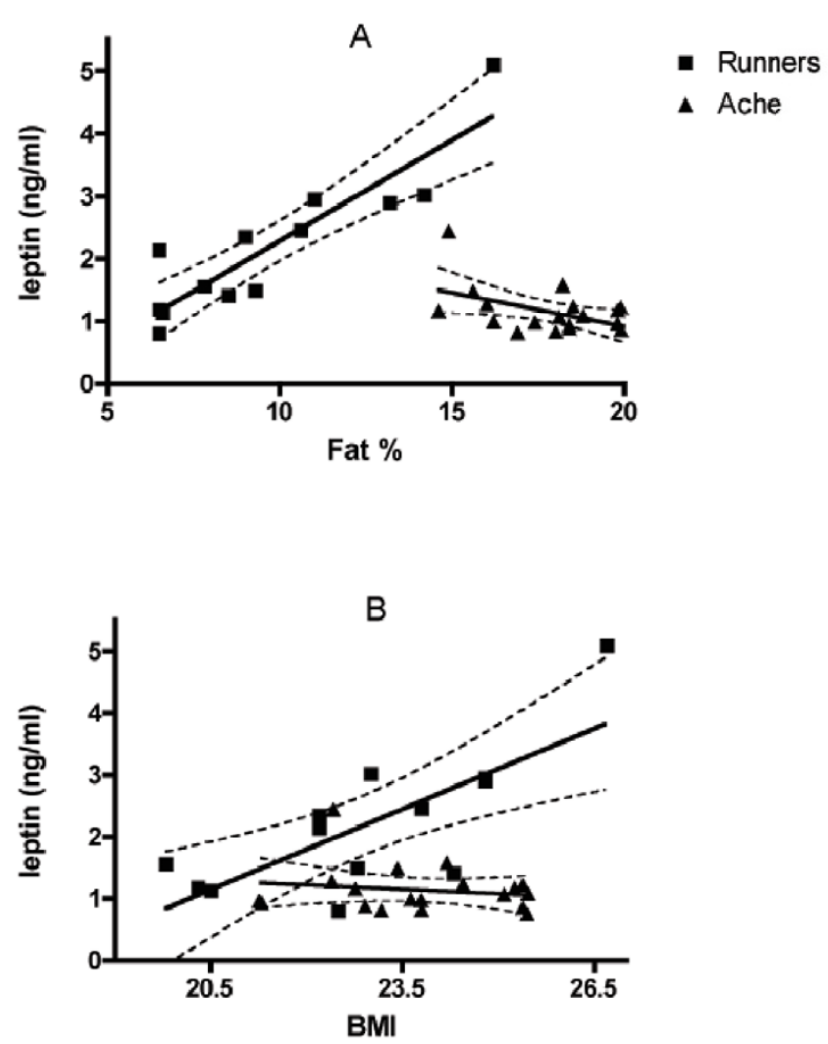

Figure 3

Associations between leptin and anthropometric measurements. Linear regression of leptin and fat \% (a) in Ache men $(r=-0.50, p<0.03)$ and runners $(r=0.90, p<$ $0.000 \mathrm{I})$. Slopes are significantly different $(\mathrm{p}<0.000 \mathrm{I}, \mathrm{F}=$ 40.0); (b) in Ache men ( $r=-0.17, p<0.50)$ and runners $(r=$ $0.75, p<0.003)$. Slopes are significantly different $(p<0.00 I, F$ $=13.5)$.

such as diet and physical activity may be contributory. Since American runners were chosen due to their leanness and physical activity compared to the Ache, it is unlikely that acute differences in daily lifestyle patterns related to adiposity and physical activity were a factor in this study.

Genetic differences in the Ob gene that codes for leptin as well as its receptor are also possible sources of variation. For example among Taiwanese aboriginal populations, greater incidences of obesity were associated with the G2548 A polymorphism in the promoter region of the leptin gene and the Gln223Arg (Q223R) polymorphism of the leptin receptor gene [18]. Similar findings are evident among Brazilian populations [19]. Variation in the proopiomelanocortin gene has also been associated with variation in leptin levels [20]. While various genetic analyses have been conducted among the Ache, descriptions of potential genetic leptin polymorphisms remain to be conducted. The Ache are a genetically homogeneous popula- tion and unique leptin polymorphisms may be possible [21].

McMillen and colleagues have emphasized the potential role of early developmental processes that may affect leptin and adipose physiology later in adulthood. They suggest high maternal BMI may lead to greater circulating glucose in fetuses and altered adipocyte metabolism during childhood, ultimately leading to greater leptin levels in adulthood and a propensity towards obesity [10]. However the inverse may be at play with the Ache. Among the Ache, maternal undernutrition may lead to lower adult leptin levels. One Ache woman, nine months pregnant, exhibited very low leptin levels (bottom $5^{\text {th }}$ percentile compared to American pregnant women) (unpublished data). However clearly further data on pregnancy and leptin are needed among the Ache.

In addition, a comparison of leptin between well-fed Italian and undernourished Gambian boys and girls revealed that Gambian children exhibited consistently lower leptin even after controlling for BMI [22]. Animal models have also shown that early exposure to leptin increases receptor formation in the hypothalamus [23]. Leptin clearance rates are also positively associated with adiposity, although relationships with population variation are unknown [24]. Conversely, a comparison of leptin among Pima Indian populations living under differing lifestyle and environmental conditions revealed that under conditions of high caloric intake/low energy expenditure (American) compared to low caloric intake/high energy expenditure (Mexican), leptin was significantly higher among the Mexican Pima independent of sex, adiposity, and insulin resistance state [25].

In adults, leptin levels and adipose tissue production rates exhibited a more prominent decline in fasted lean women compared to fasted obese women [26], while five days of intense active military training also decreased leptin levels in healthy men, most likely due to hypoinsulinemia and increases in catecholamines [3]. However both Ache and American runner men are very physically active. Therefore daily physical exertion may contribute to their low leptin levels compared to more sedentary men, but it does not account for the lack of association between leptin and adiposity among the Ache. Interestingly, elite male and female gymnasts exhibit hypoleptinemia and associated delays in puberty and other developmental challenges, suggesting continued effects on lower leptin production in adulthood [27]. However leptin responses to heavy endurance training exhibited only a modest increase in elite runners [28]. The Ache also undergo later puberty compared to American counterparts [29], intimating the potential role of energetic status during pubertal development and later adipose leptin production rates. Finally, 
zinc deficiency induces acute hypoleptinemia [30-33], however oral zinc supplementation did not affect Ache male leptin levels [34].

Immunological stress, while not quantified in this study, likely differed between Ache and American runner men. Chronic and acute infections affect and are influenced by leptin levels [5,35]. Specific aspects of Ache disease epidemiology are not well described. However, tuberculosis is becoming more common within the Ache community and may be a factor to consider [36]. Curiously, Yüksel and colleagues [37] reported that serum leptin levels were higher among active tuberculosis patients compared to controls. Treatment elevated leptin levels even higher. Schwenk et al. [38] also reported that wasting associated with tuberculosis was unrelated to leptin. It is therefore unlikely that possible tuberculosis infection made any significant contribution to Ache leptin profiles although the role of other infectious agents remain to be investigated.

While leptin likely serves as a fat cell mass/energy signal to the central nervous system, acute underfeeding can dramatically lower systemic leptin independent of changes in adipose tissue mass [2]. This is in accordance with the hypothesis that leptin may serve as an anti-starvation as opposed to an anti-obesity signal. The unusually low leptin in Ache males and females may be part of a coordinated metabolic milieu that is geared toward restrained energy intake and storage, as the environment is much more tenuous than a Western environment with abundant energy dense foods and little physical activity. Such a state is consistent with the thrifty genotype hypothesis and may contribute to contemporary high rates of obesity among Native American populations $[39,40]$.

Foraging populations are excellent models for assessing the evolutionary implications of exercise physiology. Assessments of physical performance of the Ache have provided evolutionary physiologists with important insights into human biology and their responses to physical activity, both recreational and non-recreational [14]. Indeed, long distance running is a popular exercise activity may be rooted in the evolution of human physiology. Not only is skeletomuscular adaptation required, an efficient suite of metabolic mechanisms are also necessary to manage energy usage during this period of acute activity. Indeed, running has been suggested to have been a central factor in the evolution of habitual bipedalism [41]. Although investigations of our hominid ancestors are limited to examinations of the fossil record, research among contemporary hunter/gatherers and other non-industrial populations are useful models of the ecological, energetic, and lifestyle challenges that were probably not unlike those that confronted human ancestors. The effects of acute activity among forager populations suggests that chronic differences in lifestyle and ecological circumstance may influence physiological function $[14,42]$.

The significant non-pathological range of variability in leptin and other metabolic hormones merits greater awareness and appreciation on the part of human biologists. Moreover, the growing incidence of obesity, metabolic syndrome, and diabetes, along with increasing population heterogeneity due to immigration, strongly advocates that diagnostic and research clinicians would surely benefit from recognizing the importance of leptin variation independent of adiposity.

\section{Conclusion}

While adiposity has been repeatedly shown to be central to leptin production and circulating levels, we have provided further evidence that leptin levels exhibit a significant range of variation independent of somatic condition, most importantly adiposity. Leptin production rate varies in association with environmental conditions and contributes to population variation. Further research is necessary to ascertain the potential implications for differences in the incidence and etiology of obesity, diabetes, and other metabolic disorders among ethnicities and populations.

\section{Competing interests}

The authors(s) declare that they have no competing interests.

\section{Authors' contributions}

Dr. Richard G. Bribiescas initiated the research question addressed in this manuscript, performed the field collection and conducted the laboratory analysis of the Ache hormonal and anthropmetric data, performed the statistical analysis, as well as contributed to the preparation and editing of the manuscript. He also initiated and procured the grants necessary to collect the Ache data.

Dr. Matthew S. Hickey contributed to the collection and laboratory analysis of the American runner hormonal and anthropometric data. He also assisted in the preparation and editing of the manuscript. Both authors were involved with the preparation and editing of the final manuscript.

\section{Acknowledgements}

The author thanks the Ache community of Puerto Barra and members of the Yale University Reproductive Ecology Laboratory for their cooperation and support. This research partially funded by a Yale Faculty Social Science Research Grant to RGB.

\section{References}

I. Casanueva FF, Dieguez C: Neuroendocrine regulation and actions of leptin. Front Neuroendocrinol 1999, 20:317-363.

2. Mars M, de Graaf C, de Groot LC, Kok FJ: Decreases in fasting leptin and insulin concentrations after acute energy restric- 
tion and subsequent compensation in food intake. Am J Clin Nutr 2005, 8 I:570-577.

3. Gomez-Merino D, Chennaoui M, Drogou C, Bonneau D, Guezennec $C Y$ : Decrease in serum leptin after prolonged physical activity in men. Med Sci Sports Exerc 2002, 34:1594-1599.

4. Paracchini V, Pedotti P, Taioli E: Genetics of leptin and obesity: a HuGE review. Am J Epidemiol 2005, 162:10I-II4.

5. Lord G: Role of leptin in immunology. Nutr Rev 2002, 60:S35-8; discussion S68-84, 85-7.

6. Cinti S, de Matteis R, Ceresi E, Pico C, Oliver J, Oliver P, Palou A, Obrador A, Maffeis C: Leptin in the human stomach. Gut 200I, 49:155.

7. Perez-Bravo F, Albala C, Santos JL, Yanez M, Carrasco E: Leptin levels distribution and ethnic background in two populations from Chile: Caucasian and Mapuche groups. Int J Obes Relat Metab Disord 1998, 22:943-948.

8. Lindgarde F, Widen I, Gebb M, Ahren B: Traditional versus agricultural lifestyle among Shuar women of the Ecuadorian Amazon: effects on leptin levels. Metabolism 2004, 53:1355-1358.

9. Bribiescas RG: Serum leptin levels and anthropometric correlates in Ache Amerindians of eastern Paraguay. Am J Phys Anthropol 200I, I I 5:297-303.

10. McMillen IC, Edwards LJ, Duffield J, Muhlhausler BS: Regulation of leptin synthesis and secretion before birth: implications for the early programming of adult obesity. Reproduction 2006, | 3 I:4|5-427.

II. Bribiescas RG: Serum leptin levels in Ache Amerindian females with normal adiposity are not significantly different from American anorexia nervosa patients. Am J Hum Biol 2005, 17:207-210.

12. Resnick HE: Metabolic syndrome in American Indians. Diabetes Care 2002, 25:1246-1247.

13. Lindgarde F, Soderberg S, Olsson T, Ercilla MB, Correa LR, Ahren B: Overweight is associated with lower serum leptin in Peruvian Indian than in Caucasian women: A dissociation contributing to low blood pressure? Metabolism 200I, 50:325-329.

14. Walker R, Hill K: Modeling growth and senescence in physical performance among the ache of eastern Paraguay. Am J Hum Biol 2003, 15: 196-208.

15. Hickey MS, Considine RV, Israel RG, Mahar TL, McCammon MR, Tyndall GL, Houmard JA, Caro JF: Leptin is related to body fat content in male distance runners. Am J Physiol 1996, 27 I:E938-40.

16. Frederich R, Hu S, Raymond N, Pomeroy C: Leptin in anorexia nervosa and bulimia nervosa: importance of assay technique and method of interpretation. J Lab Clin Med 2002, 139:72-79.

17. Zar JH: Biostatistical analysis. 4th edition. Upper Saddle River, N..., Prentice Hall; 1999:I v. (various pagings).

18. Wang TN, Huang MC, Chang WT, Ko AM, Tsai EM, Liu CS, Lee CH, Ko YC: G-2548A polymorphism of the leptin gene is correlated with extreme obesity in Taiwanese aborigines. Obesity (Silver Spring) 2006, 14:183-187.

19. Duarte SF, Francischetti EA, Genelhu-Abreu V, Barroso SG, Braga JU, Cabello PH, Pimentel MM: p.Q223R leptin receptor polymorphism associated with obesity in Brazilian multiethnic subjects. Am J Hum Biol 2006, I 8:448-453.

20. Hixson JE, Almasy L, Cole S, Birnbaum S, Mitchell BD, Mahaney MC, Stern MP, MacCluer JW, Blangero J, Comuzzie AG: Normal variation in leptin levels in associated with polymorphisms in the proopiomelanocortin gene, POMC. J Clin Endocrinol Metab 1999, 84:3|87-3|9|.

21. Schmitt R, Bonatto SL, Freitas LB, Muschner VC, Hill K, Hurtado AM, Salzano FM: Extremely limited mitochondrial DNA variability among the Ache Natives of Paraguay. Ann Hum Biol 2004, 31:87-94.

22. Moore SE, Falorni A, Bini V, Fulford AJ, O'Connell MA, Prentice AM: Ethnic differences in the relationship between fasting leptin and BMI in children. Int J Obes Relat Metab Disord 2004, 28: I7-2I.

23. Morash BA, Imran A, Wilkinson D, Ur E, Wilkinson M: Leptin receptors are developmentally regulated in rat pituitary and hypothalamus. Mol Cell Endocrinol 2003, 210:1-8.

24. Wong SL, DePaoli AM, Lee JH, Mantzoros CS: Leptin hormonal kinetics in the fed state: effects of adiposity, age, and gender on endogenous leptin production and clearance rates. J Clin Endocrinol Metab 2004, 89:2672-2677.
25. Fox C, Esparza J, Nicolson M, Bennett PH, Schulz LO, Valencia ME, Ravussin E: Plasma leptin concentrations in Pima Indians living in drastically different environments. Diabetes Care 1999, 22:413-4I7.

26. Klein S, Horowitz JF, Landt M, Goodrick SJ, Mohamed-Ali V, Coppack SW: Leptin production during early starvation in lean and obese women. Am J Physiol Endocrinol Metab 2000, 278:E280-4.

27. Weimann E, Blum WF, Witzel C, Schwidergall S, Bohles HJ: Hypoleptinemia in female and male elite gymnasts. Eur J Clin Invest 1999, 29:853-860.

28. Ishigaki T, Koyama K, Tsujita J, Tanaka N, Hori S, Oku Y: Plasma leptin levels of elite endurance runners after heavy endurance training. J Physiol Anthropol Appl Human Sci 2005, 24:573-578.

29. Hill K, Hurtado AM: Ache life history : the ecology and demography of a foraging people. In Foundations of human behavior New York, Aldine de Gruyter; 1996:xix, 561.

30. Chen MD, Song YM, Lin PY: Zinc may be a mediator of leptin production in humans. Life Sci 2000, 66:2/43-2।49.

31. Mangian HF, Lee RG, Paul GL, Emmert JL: Zinc deficiency suppresses plasma leptin concentrations in rats. I Nutr Biochem 1998, 9:47-5I.

32. Mantzoros CS, Prasad AS, Beck FW, Grabowski S, Kaplan J, Adair C, Brewer $G$ ]: Zinc may regulate serum leptin concentrations in humans. J Am Coll Nutr 1998, 17:270-275.

33. Ott ES, Shay NF: Zinc deficiency reduces leptin gene expression and leptin secretion in rat adipocytes. Exp Biol Med (Maywood) 200I, 226:84I-846.

34. Bribiescas RG: Effects of oral zinc supplementation on serum leptin levels in Ache males of eastern Paraguay. Am J Hum Biol 2003, 15:68I-687.

35. Matarese G, Moschos S, Mantzoros CS: Leptin in immunology. J Immunol 2005, I74:3|37-3|42.

36. Hurtado AM, Hill KR, Rosenblatt W, Bender J, Scharmen T: Longitudinal study of tuberculosis outcomes among immunologically naive Ache natives of Paraguay. Am J Phys Anthropol 2003, I 21:134-150.

37. Yuksel I, Sencan M, Dokmetas HS, Dokmetas I, Ataseven H, Yonem $O$ : The relation between serum leptin levels and body fat mass in patients with active lung tuberculosis. Endocr Res 2003 , 29:257-264.

38. Schwenk A, Hodgson L, Rayner CF, Griffin GE, Macallan DC: Leptin and energy metabolism in pulmonary tuberculosis. $\mathrm{Am} J \mathrm{Clin}$ Nutr 2003, 77:392-398.

39. Ravussin E, Pratley RE, Maffei M, Wang H, Friedman JM, Bennett PH, Bogardus C: Relatively low plasma leptin concentrations precede weight gain in Pima Indians. Nat Med 1997, 3:238-240.

40. Neel JV: Diabetes mellitus: a "thrifty" genotype rendered detrimental by "progress"? Am J Hum Genet 1962, I 4:353-362.

4I. Bramble DM, Lieberman DE: Endurance running and the evolution of Homo. Nature 2004, 432:345-352.

42. Worthman CM, Konner MJ: Testosterone levels change with subsistence hunting effort in !Kung San men. Psychoneuroendocrinology 1987, 1 2:449-458.

Publish with Bio Med Central and every scientist can read your work free of charge

"BioMed Central will be the most significant development for disseminating the results of biomedical research in our lifetime. "

Sir Paul Nurse, Cancer Research UK

Your research papers will be:

- available free of charge to the entire biomedical community

- peer reviewed and published immediately upon acceptance

- cited in PubMed and archived on PubMed Central

- yours - you keep the copyright 